Instructions for authors, subscriptions and further details:

http://ijep.hipatiapress.com

\title{
Measuring Preschool Children Temperament: Implications for Preschool Care and Education Practice
}

Sanja Tatalović Vorkapić, Darko Lončarić ${ }^{1}$

1) Faculty of Teacher Education, University of Rijeka

Date of publication: October 24 $4^{\text {th }}, 2015$

Edition period: October 2015 - February 2016

To cite this article: Tatalović Vorkapić, S \& Lončarić, D. (2015). Measuring preschool children temperament: Implications for preschool care and education practice. International Journal of Educational Psychology, 4(3), 280-304. doi: 10.17583/ijep.2015.1483

To link this article: http://dx.doi.org/10.17583/ijep.2015.1483

\section{PLEASE SCROLL DOWN FOR ARTICLE}

The terms and conditions of use are related to the Open Journal System and to Creative Commons Attribution License (CC-BY). 


\section{Measuring Preschool Children Temperament: Implications for Preschool Care and Education Practice}

Sanja Tatalović Vorkapić, Faculty of Teacher Education

University of Rijeka

\author{
Darko Lončarić \\ Faculty of Teacher Education \\ University of Rijeka
}

\section{Abstract}

With the aim of measuring preschool children temperament, EASI temperament Survey has been applied. Preschool teachers $(\mathrm{N}=192)$, all female, rated a total of $\mathrm{N}=3275$ children (1612 girls and 1639 boys) with mean age M 4.368 ( $\mathrm{SD}=1.482$ ) within age range between 7 months and 7.7 years. Validation for the instrument was run. Factor analysis on principal components with Oblimin rotation and reliability analysis were performed on data based on preschool teachers' ratings. Three-factor solution has been determined: Emotionality, Activity and Sociability, which have explained $57.427 \%$ variance. As it was expected, impulsivity component was not replicated. Subscales inter-correlations and gender and age differences confirmed results from prior research. Overall, the findings were discussed within the frame of preschool children temperament development and variables related to the characteristics of observers. Several significant implications for preschool teachers practice and the quality of educational process have been emphasized

Keywords: temperament, preschool children, teachers' ratings, EASI temperament survey, educational process 


\section{Medición del Temperamento de los Niños en Edad Preescolar: Implicaciones para el Cuidado Preescolar y la Práctica Docente}

Sanja Tatalović Vorkapić, Faculty of Teacher Education

University of Rijeka
Darko Lončarić

Faculty of Teacher Education

University of Rijeka

\section{Resumen}

Con el objetivo de medir el temperamento de los niños en edad preescolar, se aplicó la encuesta de temperamento EASI. Los maestros de preescolar $(\mathrm{N}=192)$, todas mujeres, midieron a un total de $\mathrm{N}=3275$ (1612 niñas y 1639 niños) con edad media de $4.368 \mathrm{M}$ ( $\mathrm{SD}=$ 1,482) con edades entre los 7 meses y 7,7 años. Se realizó la validación del instrumento. El análisis factorial de componentes principales con rotación y análisis de fiabilidad Oblimin se realizaron en los datos basados en las calificaciones del profesorado de preescolar. Se han determinado tres factores: Emotividad, Actividad y Sociabilidad, que han explicado 57,427\% de la varianza. Como se esperaba, el componente de impulsividad no se repitió. Intercorrelaciones entre las sub-escalas y las diferencias por género y edad confirmaron resultados de investigaciones previas. En general, los resultados fueron discutidos en el marco del desarrollo del temperamento de los niños de preescolar y las variables relacionadas con las características de los observadores. Se ponen de relieve implicaciones importantes para la práctica docente en preescolar y la calidad del proceso educativo.

Palabras clave: temperamento, preescolar, medidas del profesorado, encuesta temperamento EASI, proceso educativo 
7 Temperament is often defined as 'a subset of early-developing personality traits that display biological origins and are consistent ( across situations and time stimulated behavioral genetic studies of child temperament' (Spinath \& Angleitner, 1998, p. 948). It represents the set of some major individual differences in people and it is clearly demonstrated early in life (Rothbart, 2012). Moreover, it is 'relatively stable within context, but not impervious to experience' (Nigg, 2006, p. 398), what implies its strong determination by genetics and environment (Berk, 2008; Kail \& Barnfield, 2014). Nevertheless, even though the temperament research have lasted from 1950s, there are numerous theoretical models and measurement methods today (Luby et al., 1999; Merenda, 1999; Rothbart \& Mauro, 1990; Zupančič, 2008; Sleddens et al., 2012; Tatalović Vorkapić \& Lučev, 2014), what brings many disagreements about what temperament really is. In their work, Zentner and Bates (2008) and Zentner and Shiner (2012a) discuss various concepts and measures of infant and child temperament. Although, each of these measures demonstrates certain advantages and disadvantages, the EASI model of child temperament has been chosen as the basic one in this study (Buss \& Plomin, 1984), due to its potential to fulfil criteria of 'basic traits' of personality (Zentner \& Shiner, 2012a). Considering the facts that EASI dimensions have been reliable identified across methods, ages, genders and cultures (Bould, Joinson, Sterne \& Araya, 2013; Mathiesen \& Tambs, 1999), showed moderate heritability (Spinath \& Angleitner, 1998), has been recognized in non-human species (Diamond, 1957) and demonstrated significant identification with biological trait markers such as those from FFM (Angleitner \& Ostendorf, 1994; Zentner \& Shiner, 2012b), they presented as a solid option to be verified in this study. Therefore, there are two main contributions of this particular research. The first one is related with EAS temperament model verification in general. The second one is related with the enhancement of Croatian preschool practice since there is a lack of temperament measures in our country that could be reliable applied by preschool teachers.

\section{EAS Temperament Model}

Buss and Plomin $(1975,1984)$ created EASI temperament model on the basis of expansion of Diamond's 'phylogenetic' approach (1957) in defining 
the temperament. The main Diamond thesis lied on the observation that all existing models and their verifications failed to distinguish between temperament basics and their cultural elaboration. He proposed that the solution to this problem should be found in the animal world. Similarly to this proposal, Zuckerman (1991) proposed four criteria for basic traits personality as previously mentioned. He noted that there are four temperamental traits presented in the humans and animals: affiliativeness, aggressiveness, fearfulness and impulsiveness. The additional remarks of Buss and Plomin (1975, 1984) were related to the criteria of early appearance of temperamental traits in ontogenesis, their heritability and continuity throughout life span. At the beginning, the model postulated that the child's temperament could be measured in three dimensions emotionality, activity, sociability and impulsivity.

Emotionality refers to how quickly a child becomes agitated and begins to negatively react to stimuli from the environment. In other words, it presents the predisposition to get easily distressed. The children differentiate on this dimension due to their differences in their nervous system. Some children respond more quickly and automatically experience greater arousal than the others do. Thus, this particular EASI-dimension is similar to reactivity dimension in the approach of Rothbart (Rothbart \& Derryberry, 1981; Rothbart, 2011, 2012). During the first few months of life, emotionality is expressed through disapproval (such as crying), which appears in uncomfortable situations. Later in the first year, emotionality is differentiated either according to the reactions of fear either to the reactions of anger. What emotionality will children develop manifested in their behaviour depends on their experiences. Within this dimension, a child who is highly emotional may get excited quickly, be more fearful, cry easily, or show some other strong emotional responses. A child low on this dimension could appear to be more relaxed, more easy going, and less interested in his or her environment.

The 'total activity level refers to the total energy output' (Buss \& Plomin, 1975 , p. 32-33). The activity dimension presents a child tempo (speed) and energy use. Children with high ratings on this dimension are highly dynamic and constantly on the move. They are prone to explore new places and prefer physical activity and games. Their highest interest is for very stimulating 
activities, so sometimes they could be difficult to settle down. This activity level determines by how fast and how far a child can go, but the environment determines in which direction baby could move.

Finally, sociability relates to the child's level of interaction with others. It refers to the child's tendency to be with other people, i.e. the propensity to connect with others and responding to social stimuli. Children high on this dimension prefer team sports and any kind of group activities. They are more comfortable while interacting with others in social settings. Therefore, children estimated high on this dimension do not like to be alone and often encourage contact and interaction with others. On the other side, those low on sociability may prefer solitary activities and experience anxiety around strangers or new situations. Although according to this EASI-model the temperament is biologically determined, social development is explained by interaction's way. In other words, the child's levels of EASI-dimensions may be genetically determined, but the child's overall social development depends on the kind of the interaction with his/her environment (Rothbart, 2011).

Even though EASI-model of temperament originally included impulsivity, due to results of factor analysis it was excluded from the model (Buss \& Plomin, 1975). The main reason was the lack of possibility to replicate this dimension due to the fact that is composed of various components. The correlations of impulsivity with other factors were too high, so the EASI-II was created to diminish these negative sides of EASI-I. Nevertheless, further studies demonstrated the replicability of impulsivity only in school-aged children. Therefore, two measures are created: EASI-I and EASI-II Temperament Survey for Children (Buss \& Plomin, 1984). In those studies, authors did not succeed to replicate the impulsivity. So, EASII was identified as EAS temperament survey very often in relevant literature. Considering the basics of this theoretical model, EASI-I was used in this study too, even though the sample consisted of preschool children.

\section{Temperament Assessment}

Considering the temperament assessment in our country, it is important that two facts are emphasized. First, one of the reasons to run validation of EAS Temperament Survey in our country is the lack of similar instruments in 
preschool practice, which could provide preschool teachers and psychologists to collect objective and reliable data on child temperament. Secondly, it is of outmost significance that ratters of children's temperament are preschool teachers, since the context of kindergarten and developmental outcomes are very important within this particular temperament research. Therefore, even though there are numerous measures for assessing temperament, such observation scales, structured interviews, rating scale (teacher, parent and self-reports) and physiological techniques, the application of questionnaire rated by preschool teachers in this study justifies its main aim. Zentner and Bates (2008) provided a detailed overview of widely used questionnaire measures of children's temperament within which different forms of EAS Temperament Survey (according to children's age) are presented, too.

Using the questionnaire is the most common and economical. However, one should be aware of methodological problems of temperament assessments arising primarily from meta-emotions of parents and preschool teachers, which may affect the child's behaviour (Brajša-Žganec, 2002). Thus, the child's behaviour is not only the result of temperament than of educational and parental influence. It is quite logic to expect that the level of parent-teacher agreement on measures of temperament would be low. This definitely suggests rather significant contextual effects in the way children's temperament is expressed and manifested through behavioural patterns (Goldsmith, Reiser-Danner \& Briggs, 1991). Therefore, it is very important to have in minded that if developmental or learning outcomes are important, than more appropriate estimators for children's temperament would be preschool teachers, rather than parents. This is the case in this research. Furthermore, since it was reasonable to expect a certain level of disagreement between preschool teachers and parents' rating on this scale, it was expected to remove form the EASI Temperament Survey all items that are specific to home-context. Since there are no any, what is one of the major advantages of this scale because the same version could be applied among preschool teachers and parents as ratters; its full form was used in this study. Although Munis and colleagues (2007) demonstrated the significance and utility of much more complex measure for preschool teachers to use in assessing children's temperament than EAS survey, this 
study's contribution lies in the fact that there is a very small number of similar studies in our country. There is very small number of valid and reliable temperament measures to be used by preschool teachers, so this should be changed. This of course brings up a new question, which is related to finding a solution to diminishing the subjectivity of estimator or personal equation of preschool teacher, since their estimations could not be identical. The study findings of Neale and Stevenson (1989) clearly demonstrated significant ratter bias of spouses, especially with greater bias for monozygotic than for dizygotic twins. However, this could be one of the guideline for one of the future studies in this research field.

\section{Objective of the Study}

Therefore, regarding described EASI temperament model and the significance of preschool teachers to be the estimators of the children's temperament, the main aim of this study was to validate EASI Temperament Survey for children in Croatian kindergartens. What is important for preschool teachers to objectively identify and understand various children's temperament in the context of kindergarten? The answer is described the best in the outlook of Zentner and Bates (2008) and it pointed out that adults' responses to children's temperamental characteristics are crucial for their healthy temperament development. Several studies confirmed this postulate. Kochanska and colleagues $(1997,2007)$ demonstrated that gentle versus harsh way of mothers' parenting style is the best for the children who are highly fearful. The same author determined that fearless children have the healthiest development with mothers who are warm and fun. Furthermore, Arcus (2001) found that more challenging than supportive way of parenting is the best for the children who exhibit high negative emotional responses. Bates and colleagues (1998) showed that mothers who are highly controlling in response to the small child misbehaviours have the highest success in preventing of developing externalizing behaviour problems in their children. Paulussen-Hoogeboom and colleagues (2007) determined significant positive correlation between less supportive parenting with more restrictive control and children's negative emotionality. Finally, van den Akker and colleagues (2010, p. 494) 'identified negative and positive parenting as environmental mechanisms that were related to the 
development of temperament profiles over time'. Altogether demonstrated that children's temperament has the major effect on the choosing the right adults' responses, so to have a valid and reliable instrument for assessing temperament in the kindergarten presents a significant advantage in the work of preschool teacher.

\section{Method}

\section{Participants}

The study involved a total of $\mathrm{N}=192$ preschool teachers (all female) who were observing on EASI Temperament Questionnaire a total of $\mathrm{N}=3275$ children (1612 girls and 1639 boys) with mean age $\mathrm{M}=4.368$ ( $\mathrm{SD}=1.482$ ) within age range between 7 months and 7.7 years. According to collected data, assessments were carried out in 41 kindergartens with average number of five preschool teachers per one kindergarten ranging from one to 15 of them. For the purposes of this study, early and preschool institutions were selected randomly from six counties. Educators are selected as convenient sample of educators employed in these kindergartens. All children of mixed (142 teachers) and nursery (50 teachers) educational groups that normally lead by preschool teachers who have been participated in this study were assessed. In average, one educator evaluated 17 children in her educational group, within range of 1-54 children. The mean age of preschool teachers was $\mathrm{M}=34.799$ ( $\mathrm{SD}=9.581$ ) in the age range of 22-61 years, with an average working experience of $\mathrm{M}=11.987$ years $(\mathrm{SD}=9.618)$ ranging from 3 months to 42 years of service. Kolmogorov-Smirnov test showed that distributions of children age $(\mathrm{K}-\mathrm{Sz}=7.517, \mathrm{p}=0.001)$, preschool teachers' age (K$\mathrm{Sz}=2.149, \mathrm{p}=0.001)$, and their working experience $(\mathrm{K}-\mathrm{Sz}=1.916, \mathrm{p}=0.001)$ significantly differed from normal distribution.

Regarding the results from the first factor analysis, it is needed for results of children under 2.5 age to be excluded, the final sample of observed children consisted of $\mathrm{N}=2917$ children (1448 girls and 1468 boys) with average age of $\mathrm{M}=4.627(\mathrm{SD}=1.231)$ within age range between 2.5 and 7.7 years. This sample of preschool children was rated by 183 preschool teachers and average number of observed children per one preschool teacher was 16 , ranging from 1-44 children. 


\section{Measure}

For purposes of assessing the temperament, EASI Temperament Survey has (Buss \& Plomin, 1975, 1984) has been applied. This questionnaire has the purpose of assessing the children's temperament from early and preschool to late school age. It is originally created for parents to do the estimations. In this particular study, the scale that has been already translated to Croatian language and applied in Croatian studies has been used (Sindik \& BastaFrljić, 2008). It measures four behavioural categories according to which child could be more or less emotional, active, social and impulsive. Therefore, it consists of four subscales (each of them has five items) with 20 items in total. Items from determined three-factor structure (Sociability, Activity and Emotionality) could be observed in the Table 1. Impulsivity subscale items were: "Is prone to impulsivity", "Learning self-control is difficult to her/him", "Easily becomes bored", "Easy learns to resist the temptation" and "Quickly alternates toys in the game". The children's temperament is rated according to the frequency of certain behavioural patterns on the 5-point Likert scale (1-very rare, never; 2-rare; 3-sometimes; 4-often; 5-very often, always). The total result is ranging from 5-25, and results are separately calculated for each subscale. Relating to EAS reliability, Matthiesen and Tambs (1999) determined satisfactory internal consistency (Cronbach $\mathrm{r}=0.70$ ) in a four-year high stability of these results over time, with a coefficient of 0.79 (in children aged 30-50 months), and 0.68 (in children aged from 18 to 50 months). Reliability coefficient (Cronbach's alpha) of the entire questionnaire survey in Croatian sample was $\mathrm{r}=0.74$ (Kovačić, Milotti \& Benaković-Ranogejec, 2006). Test-retest reliability EASI questionnaire was high when mothers were assessed preschool children in two consecutive months (Buss \& Plomin, 1984). In the study of Sindik and Basta-Frljić (2008) the reliability coefficient (Cronbach's alpha) of the whole questionnaire was 0.71 , and for each subscales as follows: emotionality $\mathrm{r}=0.71$; activity $\mathrm{r}=0.73$; sociability $\mathrm{r}=0.68$; and impulsivity $\mathrm{r}=0.62$. 


\section{Procedure}

The study was conducted in the institutions for early and preschool care and education in six counties and twenty-five cities: Istarska $\mathrm{N}=42$ (Višnjan, Umag, Pazin, Medulin, Labin, Fažana), Međimurska N=2 (Čakovec), Primorsko-goranska N=103 (Viškovo, Rijeka, Rab, Opatija, Novi Vinodolski, Matulji, Malinska, Lovran, Krk, Kostrena, Klana, Crikvenica), Sisačko-moslavačka N=5 (Sisak), Zadarska N=10 (Novalja, Biograd) and Zagrebačka N=38 (Zagreb) Counties. Cities and counties in kindergartens were selected randomly. Figure 1 is presenting the number of preschool teachers by each city.

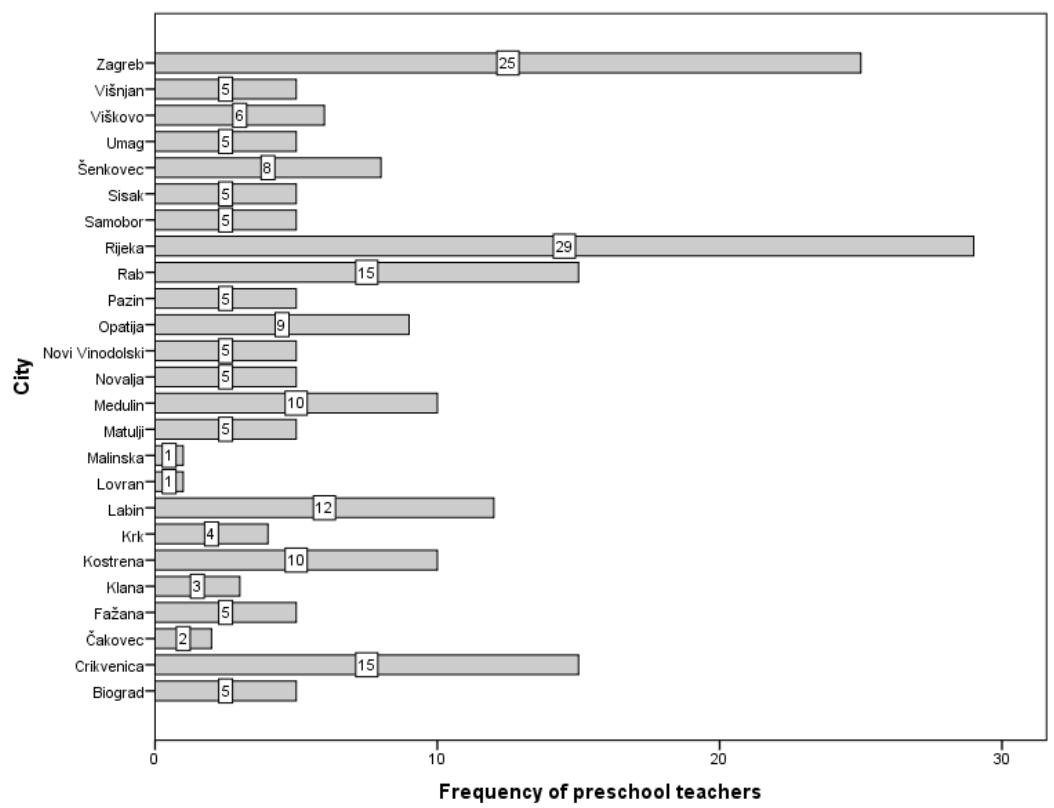

Figure 1: Bar chart of the frequency of preschool teachers by each city from six counties 
Considering the ethical requirements, the kindergartens' managers were asked to read and accept detailed informed consent for participating in this research. After obtaining the consent by the managers, informed consent was presented to the parents of all children who were attending these kindergartens. Finally, after getting parents' consent for participation in the research, all preschool teachers have been informed about the aim of this study and the phase of collecting the research data could start. With the EAS Temperament Survey, preschool teachers have received instruction how to rate children's temperament. Preschool teachers, same as parents, were familiar with the information that the research is voluntary and anonymous. Data confidentiality has ensured in the way that all preschool teachers had their own codes, same as each child had its own code. It was emphasized to preschool teachers that they should do temperament assessment only in those groups where they know the children. The instruction they get was:

In front of you is the temperament survey and you should rate the every child in your group you coded before on presented items. Estimate one child's temperament at a time, after 3-5 days of observations - if you know a child (group) before, you will need less time to evaluate. Do not assess the children all at once, but the first day of a one third, the second day of the second third and the third day of the last third of children. Upon completion of the assessment, please check if you miss any item. Upon completion of this research, detailed feedback will be given to all kindergartens that have been participated in the research. Thank you for your cooperation. " Upon completion of the assessment, the researchers collected completed questionnaires (one filling scale has lasted between 5-7 days), and overall data collection has lasted for 6 months.

Data analysis included the exploratory and confirmatory factor analysis component model (Hotelling) with Oblimin rotation, reliability analysis, descriptive analysis and analysis of variance by gender. 


\section{Results and Discussion}

In the Table 1, the items that were retained in the final factor structure with their communalities and factors' saturations on the principal components could be seen. In addition, their basic descriptive parameters, means and standard deviations could be analysed.

In the first step, conducted exploratory factor analysis with Oblimin rotation resulted indeed in a 4-factor structure, but the arrangement of items was completely different with the existing theoretical concept. Especially, impulsivity subscale items were dispersive. According to the fact, that observing and rating toddlers presented a rather specific situation of estimation (concerning the fact that it is very difficult to rate self-regulation at this age (Kail \& Barnfield, 2014) and possibility of the adaptation period to the nursery (see Mihić, 2010), it was decided to exclude all data collected within observation of toddlers of 7 months to 2.49 years. Moreover, age categories were grouped according age mid-points: $2.5-3.49=3$ years; 3.5 $4.49=4$ years; $4.5-5.49=5$ years; $5.5-6.49=6$ years; and $6.5-7.7=7$ years (Agresti, 2007; Powers \& Xie, 2008).

In the second step, exploratory and confirmatory factor analysis with Oblimin rotation was conducted again, and since impulsivity subscale items have been still very dispersive and completely disturbed the existing theoretical model, impulsivity items were excluded and three factors were inflicted. Finally, because of these two steps in conducted factor analysis, the final rotated factor matrix on the principal components with Oblimin rotation was determined (Table 1). Cattel's Scree plot has confirmed this factor solution. Three factors were retained and all of them had Eigenvalues higher than 1.00. Furthermore, it was decided to keep this final factor-structure solution regarding to the fact that Kaiser-Guttman's criteria tends to hiperfactorisation, and since this factor structure showed the least variation from the original theoretical model. Therefore, regarding the exclusion of Impulsivity factor, it could be concluded that original results of Buss and Plomin (1975, 1984) have been confirmed in this study, what was not so surprising. A valid guideline for future research drawn from this finding could be that this factor structure should be verified in school-aged sample, when the real place of impulsivity scale could be revealed. 
Table 1

Final pattern matrix of principal components: Sociability=1, Activity=2, Emotionality=3, with Oblimin rotation, communalities and descriptives for each item

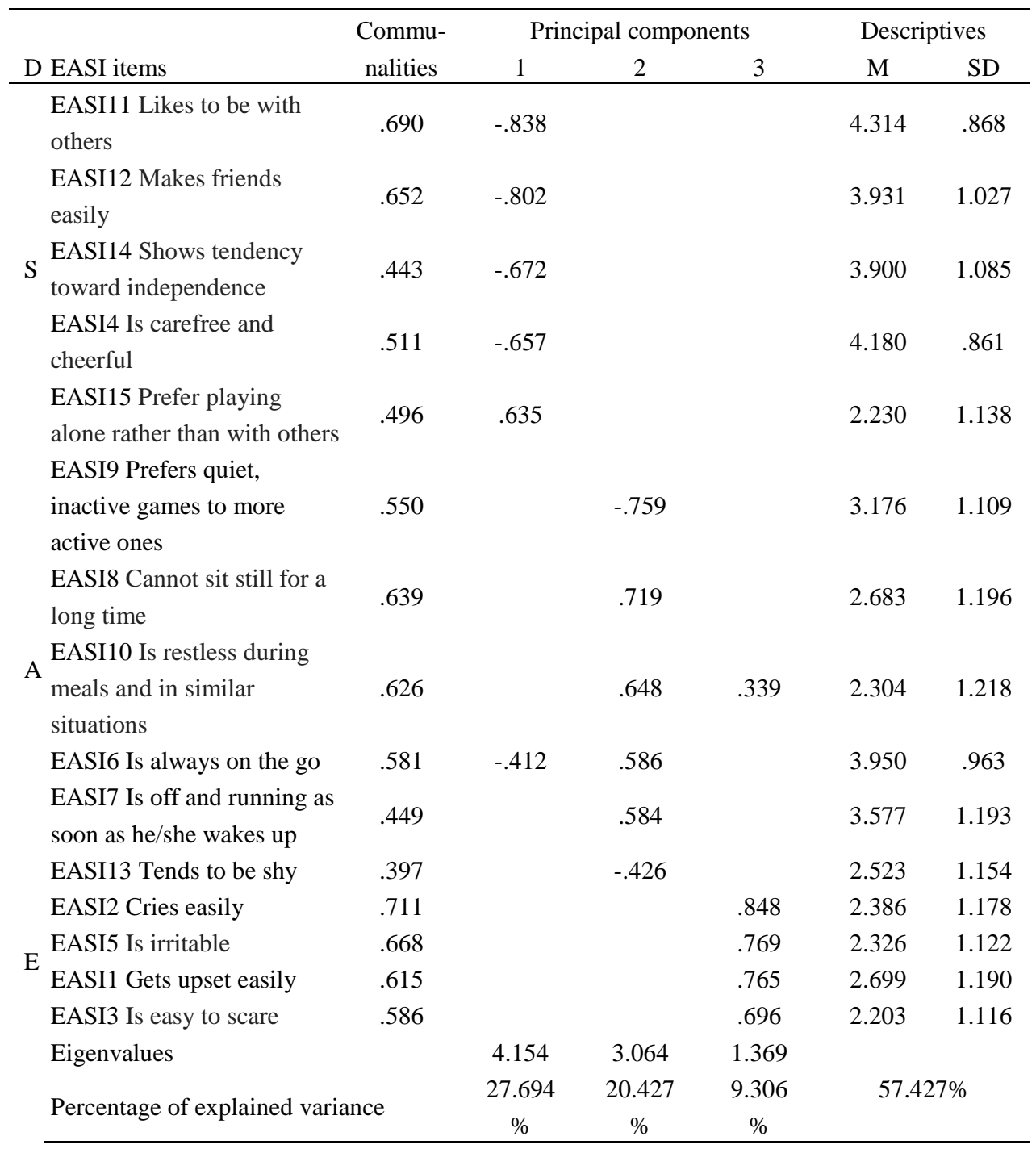


The names of determined factors are: Sociability ( $\mathrm{N}=5$ items), Activity $(\mathrm{N}=6$ items) and Emotionality ( $\mathrm{N}=4$ items), and they explained in total $57.427 \%$ of variance. Even though two items showed significant factor saturation on more than one component, it was decided to keep them since reliability analysis did not change if they have been removed. By this decision, the possibility of comparison with prior results was kept high. According to the factors structure, it could be seen that the item "Is carefree and cheerful", that was originally belongs to subscale Emotionality, showed significant saturation at the factor Sociability in this study. Moreover, item "Tends to be shy" that originally belongs to the scale Sociability, moved to the subscale Activity. These two specific findings could be explained by the variable of ratters' characteristics and the context variable. To be carefree and cheerful is definitely understood in the social context and within social interactions between children. On the other side, shyness was understood so consequently observed and rated, as a component of activity level in children, and not within social context, what is very interesting. These findings again confirmed previous studies on great relevancy on specificities of ratter and the context in which children have been observed and estimated (Munis et al., 2007).

\section{Descriptive Parameters, Reliability Levels, Age and Gender Differences Among Pre-Schoolers in EAS-Dimensions}

The means, standard deviations, reliability coefficients (Cronbach Alpha) and intercorrelation of EAS-subscales were presented in the Table 2. All three subscales showed satisfactory levels of reliability (Cronbach alpha), and the reliability levels are familiar with those from previous studies (Zentner \& Shiner, 2012a). Since, determined reliability levels are not so high, this definitely could lead us to conclusion that some other, new items would be desirable to be included in the EAS Survey, especially some that are totally context dependent. Of course, while doing this, research should properly determine if research would be carried within kindergarten context (preschool teachers as ratters) or home (parents as ratters). 
Table 2

Descriptives: Means (M), Standard deviations (SD), reliability coefficients Cronbach Alpha and Spearman correlation coefficients and significance levels for three EAS-subscales

\begin{tabular}{|c|c|c|c|c|c|}
\hline \multirow[b]{2}{*}{ EAS-subscales } & \multicolumn{2}{|c|}{ Descriptives } & \multirow{2}{*}{$\begin{array}{c}\text { Cronbach } \\
\text { alpha }\end{array}$} & \multicolumn{2}{|c|}{$\begin{array}{c}\text { EAS-subscales' } \\
\text { correlations }\end{array}$} \\
\hline & $\mathrm{M}$ & SD & & 2 & 3 \\
\hline 1.Sociability $(\mathrm{N}=5)$ & 4.019 & 0.733 & 0.785 & $0.146^{* *}$ & $-0.381 * *$ \\
\hline 2.Activity $(\mathrm{N}=6)$ & 3.136 & 0.736 & 0.720 & 1.000 & $0.161 * *$ \\
\hline $\begin{array}{l}\text { 3.Emotionality } \\
(\mathrm{N}=4)\end{array}$ & 2.402 & 0.908 & 0.808 & & 1.000 \\
\hline
\end{tabular}

$* p<0.05 ; * * p<0.01$

Intercorrelations of these three dimensions indicated the expected structure of their relationship, which is also evident in the original study (Buss \& Plomin, 1984). In addition, the determined correlations are small, so it is evident that the independence of the subscales is rather high, what has shown by factor analysis. It is reasonable to expect a significant positive correlation between activity level and negative emotionality at the one side, and from the other between activity and sociability. Although, these positive correlations are rather small, due to a large sample they are significant too. In other words, children who express high level of activity are also highly sociable and have larger amount of expressing negative emotions. It is reasonable to expect very high sociability to be related with higher activity in children. In addition, very high activity probably leads children to numerous conflicts with the environment, what could explain its significant positive relationship with negative emotionality. Moreover, very high and negative significant relationship has been determined between negative 
emotionality and sociability, what was expected. Children who often express negative emotions are less desirable within peers and had lower levels of social skills, what led them to lower sociability and behaviour problems (Orne, 2012). If the other side of the emotionality-sociability coin is observed, lower sociability kids had less social support, what brings them easily to more often experiencing negative emotions. Finally, analysing the means of EAS-subscales determined among Croatian preschoolers as rated by their preschool teachers, it could be observed that their negative emotionality is rather small, activity level moderate and the sociability level rather high. In comparison to the research of Sindik and Basta-Frljić (2008), it could be seen that preschool teachers in this study have estimated activity and sociability levels of children higher for one scale-point. Negative emotionality has been rated similar in both studies. However, in both these studies ratters were preschool teachers. For example, in the study of Bould and colleagues (2013), where estimators of children's temperaments were their mothers, the rate of negative emotionality was the same as here, but the highest rate was given to activity than to sociability level. It is possible to conclude about desirable and substantiated behavioural patterns in kindergarten depending on preschool teachers' estimations. On the other words, it is possible that, according to parents' rates, activity has the most reinforcement in difference to negative emotionality and sociability. On the other side, since preschool teachers gave the highest rates to sociability, it could be concluded that the social behaviours are the most desirable one, what is in coincidence with the aim of National curriculum framework for early and preschool care and education in Croatia (2011). Therefore, while analysing the EAS-findings in pre-schoolers it is very important to be aware of context dependency (Munis et al., 2007), what should be taken into account in every future research on preschool children's temperament.

Furthermore, age and gender differences analysis were run, and the results could be observed in the Table 3. Overall, results in this study have confirmed prior findings and theoretical assumptions (Kail \& Barnfield, 2014). Regarding the age differences in EAS-dimensions (Table 3, Figure 2), significant decline by age has been determined in negative emotionality, what was expected. 
Table 3

Main effects of age and gender differences in relation to Sociability (S), Activity (A) and Emotionality (E): ANOVA results and Scheffe test for inter-group age differences

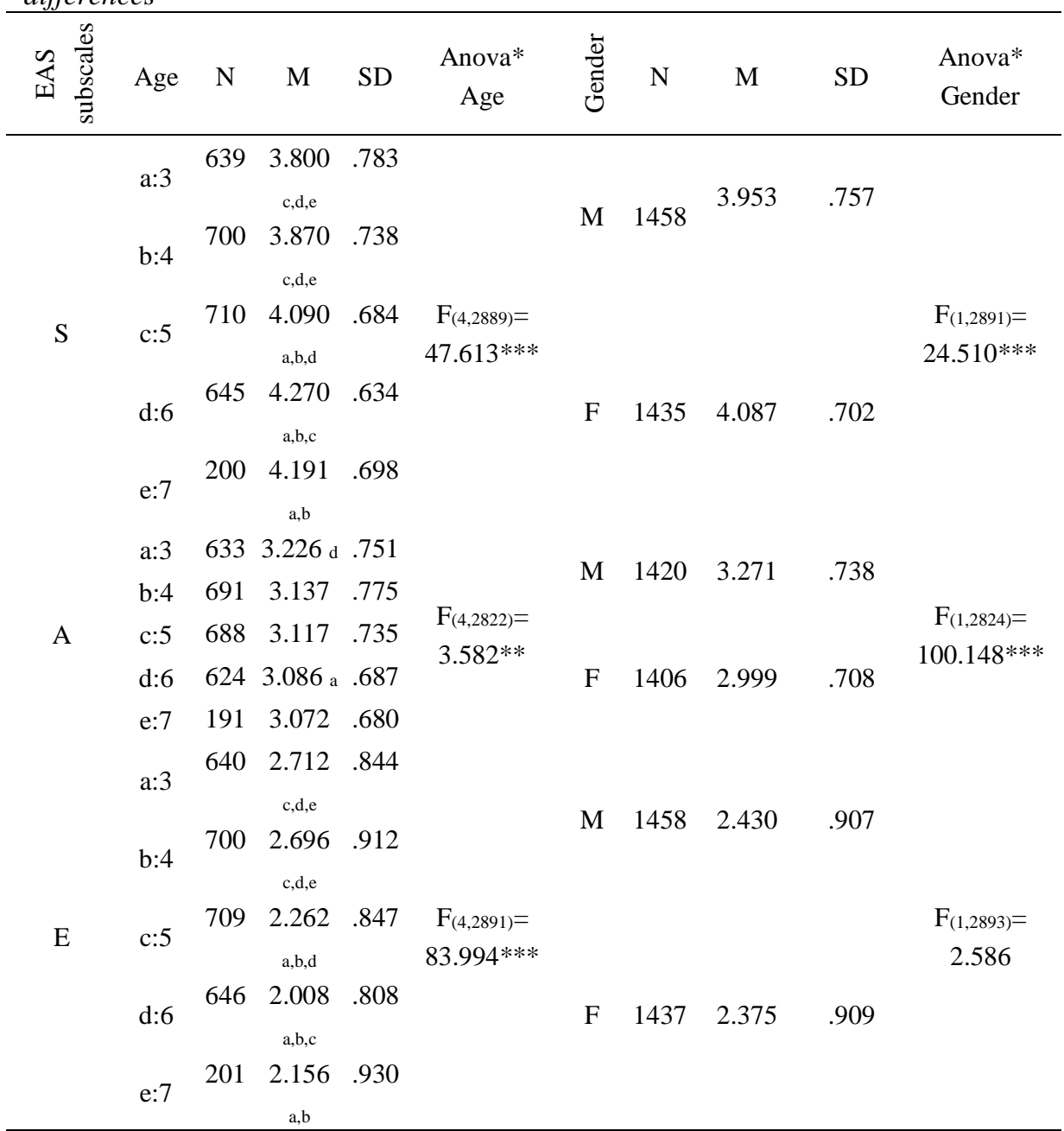

${ }^{*} p<0.05 ; * * p<0.01 ; * * * p<0.001$

Subscripts of means present the groups with statistically significant difference with other means. 
Children gain more experiences, learn how to socialize and regulate their emotional experiences, especially negative emotions, and how to protect themselves from negative experiences in general, so the negative emotionality decline by age is expected (Berk, 2008). Considering the activity level, significant decline by age could be observed only between age of three and six - other differences are not significant. This finding is similar to the observations of Buss and Plomin (1975) that there were no significant differences in activity before age of four. Finally, significant main effect of age was determined in sociability level. In other words, significant inclination of sociability has been determined by age. This finding was expected too, since higher levels of social skills and greater sociability presents one of the developmental tasks in preschool age (Berk, 2008). All findings were similar to previous research results in our country (Sindik \& Basta-Frljić, 2008) and in other countries (Bould et al., 2013).

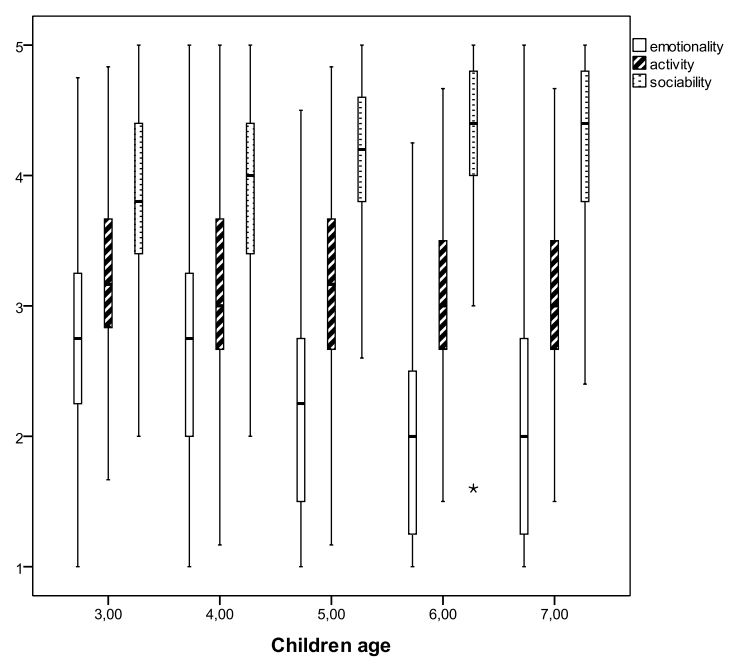

Figure 2. Boxplot of EAS-dimensions according to children's age (3, 4, 5, 6 and 7 years) 
Finally, gender differences were analyzed based on ANOVA (Table 3, Figure 3). There were no significant differences between boys and girls in negative emotionality. In difference to that, preschool teachers rated boys as significantly more active than girls and girls significantly more sociable than boys. These findings are totally in accordance with gender roles, children's socialization and the way children have been educated, within their homes and kindergartens (Rothbart, 2011).

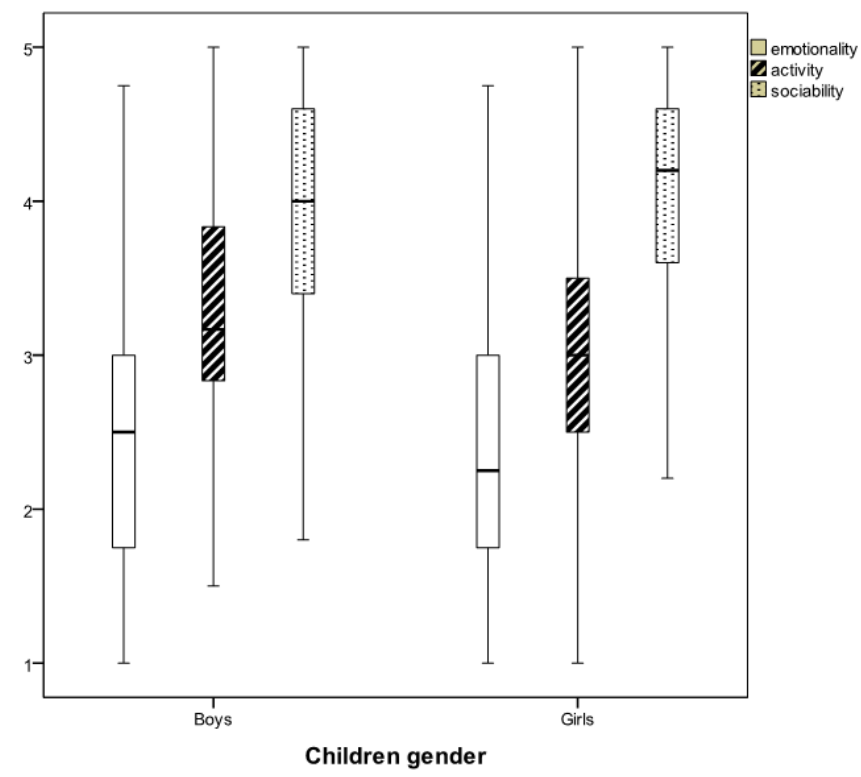

Figure 3. Boxplot of EAS-dimensions according to children's gender

\section{Conclusion}

The aim of the study was to measure preschool children temperament applying EASI Temperament Survey for Preschool Children in our country. Generally, it should be noted that three of the four subscales of the original EASI Survey have been determined in this study. After two-step of exploratory and confirmatory factor analysis on principal components with 
Oblimin rotation, the impulsivity subscale was excluded. This step was not so surprising since previous studies have demonstrated non-replicability of this scale on the sample of preschool children. On the other side, since development of self-regulation and impulsivity decline are the major developmental and educational tasks in the school aged children, it is expected for preschool teacher to recognize and rate them clearer in that later age, than in the preschool period. Therefore, the next step should include validation of EASI in our country in school-aged children.

Moreover, same as Munis and colleagues (2007) and Rothbart (2011) emphasized the context dependency showed to be the determining factor in temperament development and rating process in this study too. This could be seen in two items that showed no similarities to theoretical model of EAS, but rather the understanding of their meaning of preschool teachers who rated children's temperament. The same argument could properly serve for explanation of descriptive parameters of EAS-subscales, if they are compared to the same findings but rated by parents. Then, one could be asking: "Which estimations are closer to the real children's temperament these from preschool teachers or these from parents?". Based on this study results, some clear implications for preschool care and education practice could be drawn. Since, the main contribution of this research lies in the fact that Croatian kindergartens lack of valid, objective and reliable temperament surveys that could help preschool teachers, psychologists and pedagogists to longitudinally follow the temperament changes and characteristics of preschoolers and accordingly to that data create quality pedagogical and educational work with children, the answer to that question is not so important. What is important to be able to objectively measure children's temperament and to use these results within training programs for preschool teachers " $(. .$.$) to find rearing practices that are appropriate for a child's given$ temperament" (Zentner \& Bates, 2008, p. 29).

Finally, determined age and gender differences are consistent with developmental aspects of theoretical model and prior research results (Kail \& Barnfield, 2014). According to them, it would be very useful to conduct a longitudinal study that provides reliable answers to some questions here and possible interaction's effects. Creating research designs for future crosscultural research would provide insight into the analysis of gender 
differences, and differences in practice between institutions for early and pre-school education in different countries.

\section{References}

Agresti, A. (2007). An introduction to categorical data analysis ( $\left.2^{\text {nd }} e d.\right)$. John Wiley \& Sons, Inc., Hoboken, New Jersey, USA.

Angleitner, A. \& Ostendorf, F. (1994). Temperament and the big five factors of personality. In: C. F. Halverson, G. A. Kohnstamm \& R. P. Martin (Eds), The developing structure of temperament and personality from infancy to adulthood (pp. 69-90). Erlbaum, Hillsdale, NJ.

Arcus, D. (2001). Inhibited and uninhibited children: Biology in the social context. In T. Wachs \& G. A. Kohnstamm (Eds.), Temperament in context (pp. 43-60). Mahwah, NJ. Erlbaum.

Bates, J. E., Pettit, G. S., Dodge, K. A., \& Ridge, B. (1998). Interaction of temperamental resistance to control and restrictive parenting in the development of externalizing behavior. Developmental Psychology, 34, 982-995.

Berk, L. E. (2008). Psihologija cjeloživotnog razvoja (The psychology of life-span development. In Croatian). Jastrebarsko: Naklada Slap.

Bould, H., Joinson, C., Sterne, J. \& Araya, R. (2013). The Emotionality Activity Sociability Temperament Survey: Factor analysis and temporal stability in a longitudinal cohort. Personality and Individual Differences, 54, 628-633. doi:10.1016/j.paid.2012.11.010

Brajša-Žganec, A. (2002). Roditeljske emocije i socio-emocionalni razvoj djece, Suvremena psihologija, 5(2), 319-321.

Buss, A. H. \& Plomin, R. (1975). A temperament theory of personality development. New York: Wiley.

Buss, A. H. \& Plomin, R. (1984). Temperament: Early developing personality traits, Hillsdale, NJ: Erlbaum.

Diamond, S. (1957). Personality and temperament. New York: Harper.

Goldsmith, H. H., Reiser-Danner, L. A., \& Briggs, S. (1991). Evaluating convergent and discriminant validity of the temperament questionnaires for preschoolers, toddlers, and infants. Developmental Psychology, 27, 566-579. 
Kail, R. V. \& Barnfield, A. M. C. (2014). Children and Their Development. Third Canadian Edition. Toronto: Pearson Education Canada.

Kochanska, G. (1997). Multiple pathways to conscience for children with different temperaments: From toddlerhood to age 5. Developmental Psychology, 33, 228-240.

Kochanska, G., Aksan, N., \& Joy, M. E. (2007). Children's fearfulness as a moderator of parenting in early socialization: Two longitudinal studies. Developmental Psychology, 43, 222-237. doi: 10.1037/00121649.43.1.222

Kovačić, S., Milotti, S. \& Ranogajec-Benaković, K. (2006). Distribucija rezultata djece školskih obveznika na Upitniku temperamenta (EASI) i usamljenosti. In: J. Jelčić, J. Lopižić, G. Lugović \& Z. Sušanj (Eds.), Zbornik sažetaka - 14. godišnja konferencija hrvatskih psihologa "Ljudski potencijali kroz životni vijek", Šibenik (p. 12), Šibenik: Croatian psychological Association - Psychological Association Šibenik.

Luby, J. L., Svrakic, D. M., McCallum, K., Przybeck, T. R. \& Cloninger, C. R. (1999). The junior temperament and character inventory: Preliminary validation of a child self-report measure. Psychological Reports, 84(3c), 1127-1138. doi: 10.2466/pr0.1999.84.3c.1127

Mathiesen, K. S. \& Tambs, K. (1999). The EAS Temperament

Questionnaire: Factor Structure, Age Trends, Reliability, and Stability in a Norwegian Sample. Journal of Child Psychology and Psychiatry, 40(3), 431-439. doi: 10.1111/1469-7610.00460

Merenda, P. F. (1999). Theories, models, and factor approaches to personality, temperament, and behavioral types: Postulations and measurement in the second millennium A.D. Psychological Reports, 85(3), 905-932. doi: 10.2466/pr0.1999.85.3.905

Mihić, I. (2010). Procena kvaliteta sigurne baze u odnosu sa majkom na jaslenom uzrastu: primer skale (Secure base in mother-infant relations: an example of behavioral assessment measure. In Serbian). Primenjena psihologija, 4, 337-355.

Ministry of science, education and sports of Republic of Croatia (2011). Nacionalni okvirni kurikulum za predškolski odgoj i obrazovanje, te opće obvezno i srednjoškolsko obrazovanje. [National curriculum 
framework for early and preschool care and education, obligatory primary and secondary school education. In Croatian.] Ministry of Science, Education and Sports of RC, Zagreb. Retrieved from: http://public.mzos.hr/lgs.axd?t=16\&id=18247.

Munis, P., Greenfield, D. B., Henderson, H. A. \& George, J'L. (2007).

Development and validation of the Preschool Temperament Classification System for use with teachers. Early Childhood Research Quarterly, 22(4), 440-450. doi:

10.1016/j.ecresq.2007.09.003

Neale, M. C. \& Stevenson, J. (1989). Ratter Bias in the EASI Temperament Scales: A Twin Study. Journal of Personality and Social Psychology, 56(3), 446-455. doi: 10.1037/0022-3514.56.5.845

Nigg, J. T. (2006). Temperament and developmental psychopathology.

Journal of Child Psychology and Psychiatry, 47(3-4), 395-422. doi:

10.1111/j.1469-7610.2006.01612.x

Orne, T. (2012). Coping Styles of Maltreated Children as Related to Risk and Temperament. A Senior Thesis submitted in partial fulfillment of the requirements for graduation in the Honors Program Liberty University.

Paulussen-Hoogeboom, M. C., Stams, G. J. J. M., Hermanns, J. M. A., \& Peetsma, T. T. D. (2007). Child negative emotionality and parenting from infancy to preschool: a meta-analytic review. Developmental Psychology, 43, 438-453. doi: 10.1037/0012-1649.43.2.438

Powers, D. A. \& Xie, Y. (2008). Statistical methods for categorical data analysis ( $2^{\text {nd }} e d$. .). Emerald Group Publishing Ltd., USA.

Rothbart, M. K. (2011). Becoming who we are: Temperament and personality in development. New York: Guilford Press.

Rothbart, M. K. (2012). Advances in Temperament: History, Concepts, and Measures. In: Handbook of Temperament (Chapter 1, pp. 3-20). The Guilford Press, New York, London.

Rothbart, M. K. \& Derryberry, D. (1981). Development of individual differences in temperament. In: M. E. Lamb \& A. L. Brown (Eds.), Advances in developmental psychology (Vol 1, pp. 37-86). Hillsdale, NJ: Erlbaum. 
Rothbart, M. K. \& Mauro, J. A. (1990). Questionnaire Approaches to the Study of Infant Temperament. In J. W. Fagen \& J. Colombo (Eds.), Individual differences in infancy: Reliability, stability, and prediction (pp. 411-429). Hillsdale, NJ: Erlbaum.

Sindik, J. \& Basta-Frljić, R. (2008). Povezanost karakteristika temperamenta i spremnosti djece za školu (Connection between temperament features and readiness of children to attend school. In Croatian). Magistra Iadertina, 3(3), 147-169.

Sleddens, E. F. C., Hughes, S. C., O'Connor, T. M., Beltran, A., Baranowski, J. C., Nicklas, T. A. \& Baranowski, T. (2012). The children's behavior questionnaire very short scale: Psychometric properties and development of a one-item temperament scale. Psychological Reports, 110(1), 197-217. doi: 10.2466/08.10.21.PR0.110.1.197-217

Spinath, F. M. \& Angleitner, A. (1998). Contrast effects in Buss and Plomin's EAS questionnaire: a behavioral-genetic study on early developing personality traits assessed through parental ratings. Personality and Individual Differences, 25, 947-963. doi:10.1016/S0191-8869(98)00097-X

Tatalović Vorkapić, S. \& Lučev, I. (2014). Psychometric properties of the Croatian version of Pavlov's Temperament Survey for Preschool Children. International Journal of Psychology and Behavioral Sciences, 4(6), 193-200. doi:10.5923/j.ijpbs.20140406.02

Van den Akker, A. L., Deković, M., Prinzie, P. \& Asscher, J. J. (2010). Toddlers' Temperament Profiles: Stability and Relations to Negative and Positive Parenting. Journal of Abnormal Child Psychology, 38, 485-495. doi: 10.1007/s10802-009-9379-0

Zentner, M. \& Bates, J. E. (2008). Child temperament: An integrative review of concepts, research programs, and measures. European Journal of Developmental Sciences, 2(1/2), 7-37. doi: 10.3233/DEV-2008-21203 Zentner, M. \& Shiner, R. L. (2012a). Handbook of Temperament. The Guilford Press, New York, London.

Zentner, M. \& Shiner, R. L. (2012b). Fifty Years of Progress in Temperament Research: A Synthesis of Major Themes, Findings, and Challenges and a Look Forward. In: Handbook of Temperament (pp. 673-700). The Guilford Press, New York, London. 
Zuckerman, M. (1991). What is a basic factor and which factors are basic?

Turtles all the way down. Personality and Individual Differences, 13(6), 675-681.

Zupančič, M. (2008). The Big Five: Recent developments in Slovene child personality research. Psihološka obzorja, 17(4), 7-32.

Sanja Tatalović Vorkapić is Assistant Professor at the Faculty of Teacher Education, University of Rijeka

Darko Lončarić is Assistant Professor Faculty of Teacher Education, University of Rijeka

Contact Address: University Avenue 6, 51000 Rijeka, Croatia. email: sanjatv@ufri.hr 